\title{
IMPLEMENTASI SUPERVISI AKADEMIK KEPALA MIS BATUSANGKAR
}

\author{
Nur'ani Jumadiah, Oktazil Nurdia, Rahmi, dan Rhoni \\ Peneliti Manajemen Pendidikan Islam \\ Institut Agama Islam Negeri (IAIN) Batusangkar
}

\begin{abstract}
This study aimed at describing the implementation of academic supervision of the principal MIS Batusangkar. This research was qualitative. The subjects of this research were the principal and teachers MIS Batusanggkar. The interview was used on data collection technique.. The results showed that 1) the implementation of the academic supervision was good, it consists of planning, implementation, and evaluation; 2) the techniques used on academic supervision were teachers' meeting, visiting class, and personal dialogue; and 3) the response of teachers to the implementation of the supervision were very positive.
\end{abstract}

Keywords: Academic Supervision, Principal, Primary School, Batusangkar

\section{PENDAHULUAN}

Pendidikan adalah usaha sadar yang sengaja dirancang untuk mencapai tujuan yang telah ditetapkan. Pendidikan bertujuan untuk menungkatkan kualitas sumber daya manusia. Menurut Ki hajar dewantara pada waktu mengembangkan sistem pendidikan melalui perguruan tinggi Taman Siswa mengartikan pendidikan sebagai upaya suatu bangsa mengembangkan benih turunan bangsa itu. Sedangkan menurut M.J. Langeled, pendidikan adalah bimbingan atau pertolongan yang diberikan oleh orang dewasa kepada perkembangan anak untuk mencapai kedewasaan dengan tujuan agar anak cukup cakap melaksanakan tugas hidupnya sendiri dengan bantuan orang lain, dengan kata lain membimbing anak mencapai kedewasaan (Engkoswara dan Komariah, 2010)
Oleh karena itu pendidikan merupakan hal yang sangat penting ada dalam kehidupan ini. Kerena dengan adanya pendidikan merupakan langkah penting dalam mencerdaskan kehidupan dan membentuk watak bangsa. Hal tersebut sejalan dengan fungsi dan tujuan pendidikan nasional yang terdapat dalam UU No. 20 Tahun 2003 tentang Sistem Pendidikan Nasional yaitu pendidikan nasional berfungsi mengembangkan kemampuan dan membentuk watak serta peradaban dalam rangka mencerdaskan kehidupan bangsa, bertujuan untuk berkembangnya potensi peserta didik agar menjadi manusia yang beriman dan bertaqwa kepada Tuhan Yang Maha Esa, berakhlak mulia, sehat, berilmu, cakap, kreatif, mandiri, dan menjadi warga Negara yang demokratis serta bertanggungjawab. 
Dalam rangka pencapaian tujuan pendidikan nasional tersebut seorang Kepala Sekolah harus mampu mengelola sekolah yang dipimpinnya. Pengelolaan tersebut berkaitan dengan sumber daya yang ada di dalam sekolah yang dipimpinya tersebut.

Sekolah tidak akan berjalan sesuai dengan tujuan apabila kurangnya pengawasan yang dilakukan oleh Kepala Sekolah. Oleh karena itu peran penting Kepala Sekolah dalam melakukan pengawasan guna melihat dan menilai serta membantu kinerja dari guru agar semua kegiatan yang telah terprogram dapat berjalan secara efektif dan efisien serta sesuai dengan apa yang telah direncanakan. Hal ini sesuai dengan yang diungkapkan oleh Sergiovani seperti yang dikutip oleh Mulyasa (2007: 111) bahwa supervisi merupakan suatu proses yang dirancang secara khusus untuk membantu para guru dan supervisor dalam mempelajari berbagai macam tugasnya sehari-hari di sekolah, agar dapat menggunakan pengetahuan dan kemampuannya untuk memberikan layanan yang lebih baik pada orang tua peserta didik dan sekolah sebagai masyarakat belajar yang efektif (Mulyasa, 2012) (Jasmani dan Mustofa, 2013: 71-80).

Supervisi sangatlah penting dilakukan Kepala Sekolah, karena dengan dilakukannya supervisi oleh Kepala Sekolah maka akan dapat membantu permasalahan guru di sekolah. Berdasarkan hal tersebut peran dan fungsi Kepala Sekolah sangat diperlukan dalam meningkatkan kinerja guru. Peranan Kepala Sekolah yang harus dilaksanakan sebagaimana yang telah diatur dalam keputusan Menteri Pendidikan Nasional (Kepmendiknas) RI No. 162/U/2003 tentang pedoman penugasan guru sebagai Kepala Sekolah adalah Educator, Manager, Administrator, Supervisor, Leader, Enterpreneur, Climate Creator. Kemudian dalam Peraturan Menteri Pendidikan Nasional (Permendiknas) No. 13 Tahun 2007 tentang standar Kepala Sekolah juga menjelaskan bahwa salah satu kompetensi yang harus dimiliki seorang Kepala Sekolah adalah kompetensi supervisi.

Kepala Sekolah merupakan ujung tombak pelaksanaan supervisi yang ada di sekolah. Keberhasilan supervisi yang dilakukan oleh kepala sekolah tergantung bagaimana seorang Kepala Sekolah sebagai seorang supervisor dalam merencanakan, menjalani, dan mengevaluasi kinerja dari guru-guru yang dipimpinnya. Dalam pelaksanaan supervisi, seorang supervisor harus membuat perencanaan yang matang sebelum melasanakan supervisi. Hal tersebut senada dengan yang dikatakan oleh Kepala MIS Batusangkar, bahwa sebelum seorang Kepala Sekolah mensupervisi guru-guru, langkah pertama yang harus dilakukan adalah 
dengan merencanakan segala sesuatu yang berkaitan dengan supervisi, seperti membuat jadwal kapan guru yang bersangkutan akan disupervisi. Dengan adanya jadwal tersebut, maka guru-guru pun akan siap disupervisi.

\section{PENGERTIAN SUPERVISI AKADEMIK}

Secara bahasa supervisi berarti mengamati, mengawasi, atau membimbing kegiatan-kegiatan yang dilakukan oleh orang lain dengan maksud untuk mengadakan perbaikan. Menurut Mukhtar dan Iskandar (2009: 41) supervisi berasal dari kata "super" artinya lebih atau atas, dan "vision" artinya melihat atau meninjau. Secara estimologis supervisi artinya melihat atau meninjau yang dilakukan oleh atasan terhadap pelaksanaan kegiatan bawahannya. Sedangkan orang yang melakukan supervise disebut juga dengan supervisor.

Menurut Purwanto (1987), mengungkapkan supervisi adalah suatu aktivitas pembinaan yang direncanakan untuk membantu para guru dan pegawai sekolah lainnya dalam melakukan pekerjaan mereka secara efektif. Menurut Sergiovani dan Starrat, supervisi merupakan suatu proses yang dirancang secara khusus untuk membantu para guru dan supervisor dalam mempelajari tugas sehari-hari di sekolah; agar dapat menggunakan pengetahuan dan kemampuannya untuk memberikan layanan yang lebih baik pada orang tua peserta didik dan sekolah, serta berupaya menjadikan sekolah sebagai masyarakat belajar yang lebih efektif (Mulyasa, 2004: 111).

Konsep supervisi didasarkan atas keyakinan bahwa perbaikan merupakan suatu usaha yang kooperatif dari semua orang yang berpartisipasi dan supervisor yang bertindak sebagai stimulator, pembimbing, dan konsultan bagi para tenaga pendidik dalam rangka upaya perbaikan. Supervisi yang dilakukan oleh pengawas satuan pendidikan, tentu memiliki misi yang berbeda dengan supervisi oleh kepala sekolah. Dalam hal ini supervisi lebih ditujukan untuk memberikan pelayanan kepada kepala sekolah dalam melakukan pengelolaan kelembagaan secara efektif dan efesien serta mengembangkan mutu kelembagaan pendidikan.

Supervisi akademik adalah pembinaan yang menitikberatkan pengamatan pada masa akademik yang langsung berada dalam lingkup kegiatan pembelajaran yang dilakukan oleh guru-guru untuk membantu siswa ketika sedang dalam proses belajar (Mukhtar dan Iskandar, 2009: 43). Kesimpulannya supervisi akademik, kegiatan membantu guru secara langsung dalam mengelola prosses pembelajaran untuk mencapai tujuan akademik. Demikian guru sangat membutuhkan pengawasan dari seorang supervisor yang akan mengevaluasi 
dan dapat meningkatkan kualitas pengajaran guru.

\section{PRINSIP SUPERVISI AKADEMIK}

Menurut Sahertian (2000: 20) prinsipprinsip supervisi dapat disebutkan sebagai berikut:

1. Prinsip ilmiah yang mencakup unsur-unsur sebagai berikut 1) sistematis, yaitu dilaksanakan secara teratur, berencana dan kontinu; 2) objektif, artinya data yang didapat berdasarkan pada observasi nyata, bukan tafsiran pribadi; 3) menggunakan alat/instrument seperti angket, observasi, dan percakapan pribadi yang dapat memberikan informasi sebagai umpan balik untuk mengadakan penilaian terhadap proses belajar mengajar.

2. Prinsip demokratis, servis dan bantuan yang diberikan kepada guru berdasarkan hubungan kemanusiaan yang akrab. Demokratis mengandung makna menjunjung tinggi harga diri dan martabat guru, bukan berdasarkan atasan dan bawahan, tapi berdasarkan rasa kejawatan;

3. Prinsip kerja sama, seluruh staf sekolah dapat bekerjasama, mengembangkan usaha bersama dalam menciptakan situasi belajar mengajar yang lebih baik. Sharing of idea, sharing of experience, memberi support (mendorong), menstimulasi guru, sehingga mereka merasa tumbuh bersama; dan
4. Prinsip konstruktif dan kreatif, membina inisiatif guru serta mendorongnya untuk aktif menciptakan suasana di mana tiap orang merasa aman dan dapat mengembangkan potensi-potensinya. Prinsip ini menekankan bahwa kegiatan supervisi dilaksanakan untuk membangun dan mengembangkan potensi kreatif para guru. Supervisi diharapkan dilaksanakan dalam suasana yang menyenangkan, bukan menakut-nakuti. Dengan begitu para guru lebih termotivasi untuk mengembangkan potensi mereka.

\section{TEKNIK SUPERVISI AKADEMIK}

1. Menurut Gwyn (1963: 326-327) bahwa teknik dalam supervisi itu ada dua yaitu 1) teknik individual (perkunjungan kelas, observasi kelas, percakapan pribadi, intervisitasi, penyeleksi berbagai sumber materi untuk mengajar dan menilai diri sendiri); 2) teknik kelompok (pertemuan orientasi bagi guru baru, panitia penyelenggara, rapat guru) (Sahertian, 2000: 52-87).

2. Menurut Tim Dosen Administrasi Pendidikan Universitas Pendidikan Indonesia (2014: 317-318), bahwa teknik yang digunakan dalam supervisi akademik antara lain kunjungan kelas, pertemuan pribadi, rapat staf, kunjungan antar kelas, kunjungan sekolah, dan kunjungan antar sekolah; 
3. Menurut Engkoswara dan Komariah (2010: 230) bahwa teknik supervisi yaitu kunjungan sekolah, kunjungan kelas, kunjungan antar kelas, pertemuan pribadi, rapat guru, penerbitan bulletin professional, dan penataran; dan

4. Menurut Jasmani dan Mustofa (2013: 7180) bahwa teknik supervisi yakni: kunjungan dan observasi kelas, pembicaraan individual, diskusi kelompok, demonstrasi mengajar, bulitin supervisi, kunjungan rumah, intervisitasi, workshop/lokalkarya, in-seivice traning, dan rapat sekolah.

\section{KOMPETENSI SUPERVISI AKADEMIK KEPALA SEKOLAH}

\section{Dalam Permendiknas Nomor 13}

Tahun 2007 tentang Standar Kepala Sekolah, ada tiga kompetensi supervisi yang harus dimiliki kepala sekolah dalam rangka melaksanakan supervisi akademik yaitu 1) merencanakan program supervisi akademik dalam rangka peningkatan profesionalisme guru; 2) melaksanakan supervisi akademik terhadap guru dengan menggunakan pendekatan dan teknik supervisi yang tepat; dan 3) menindaklanjuti hasil supervisi akademik terhadap guru dalam rangka peningkatan profesionalisme guru.

\section{TUGAS DAN TANGGUNG JAWAB KEPALA SEKOLAH SEBAGAI SUPERVISOR}

Kepala sekolah sebagai supervisor dapat dilakukan secara efektif antara lain melalui diskusi kelompok, kunjungan kelas, pembicaraan individual, dan simulasi pembelajaran.

1. Diskusi kelompok, merupakan suatu kegiatan yang dilakukan bersama guruguru dan bisa juga melibatkan tenaga administrasi, untuk memecahkan berbagai masalah di sekolah, dalam mencapai suatu keputusan. Banyak masalah yang dapat dipecahkan dalam diskusi kelompok, seperti peningkatan kemampuan tenaga kependidikan, dan masalah hasil temuan kepala sekolah pada kegiatan observasi di dalam atau di luar kelas.

2. Kunjungan kelas, dapat digunakan oleh kepala sekolah sebagai salah satu teknik untuk mengamati kegiatan pembelajaran secara langsung. Kunjungan kelas merupakan teknik yang sangat bermanfaat untuk mendapatkan informasi secara langsung tentang berbagai hal yang berkaitan dengan profesionalisme guru dalam melakukan tugas pokoknya mengajar, terutama dalam pemilihan dan penggunaan metode pembelajaran, media yang digunakan oleh guru dalam pembelajaran, serta mengetahui secara langsung pengetahuan peserta didik dalam 
menangkap materi yang diajarkan. Dalam kunjungan kelas/observasi kelas, pengawas dapat melakukan pengamatan tentang 1) kesiapan mengajar guru; 2) kesiapan belajar siswa; 3) penguasaan materi yang akan disajikan; 4) kemampuan menggunakan berbagai metode belajar mengajar; 5) kemampuan memanfaatkan sarana, alat dan media pembelajaran; dan 6) Kemampuan membuka dan menutup pelajaran.

3. Pembicaraan individual, merupakan teknik bimbingan dan konseling kepada guru, baik berkaitan dengan kegiatan pembelajaran maupun masalah yang menyangkut profesionalisme guru.

4. Simulasi pembelajaran, merupakan suatu teknik supervisi berbentuk demonstrasi pembelajaran yang dilakukan oleh kepala sekolah, sehingga guru dapat menganalisa penampilan yang diamatinya sebagai intropeksi diri, walaupun sebenarnya tidak ada cara mengajar yang paling baik.

\section{IMPLEMENTASI PROGRAM SUPERVISI DI SEKOLAH}

Implementasi supervisi di lapangan banyak terjadi keragaman dalam memahami dan melaksanakan supervisi. Hal ini terjadi karena diakibatkan oleh perbedaan latar belakang pendidikan dan tingkat jabatan, perbedaan dalam orientasi profesional, perbedaan dalam tujuan dan keterampilan menganalisa, perbedaan dalam kesangupan jasmani dan vitalitas hidup, perbedaan dalam kualifikasi kemampuan untuk memimpin dan berdiri untuk dipimpin, perbedaan dalam kondisi psikologis, perbedaan dalam pengalaman belajar mengajar, serta perbedaan dalam kesanggupan dan sikap profesional.

Perbedaan tersebut seharusnya tidak menjadi penghambat dalam pencapaian tujuan supervisi profesional. Sikap supervisor yang memaksakan kehendak, menekan guru, yang melumpuhkan kreatifitas anggota staf perlu diubah. Sikap korektif yang mencari-cari kesalahan harus diganti dengan sikap kreatif di mana setiap orang mau dan mampu menumbuhkembangkan kreatifitasnya untuk perbaikan pengajaran. Penilaian pelaksanaan supervisi yang dilakukan oleh kepala sekolah merupakan salah satu cara untuk mengetahui kelemahan pelaksanaan pembinaan maupun faktor yang memberinya harapan dalam kemudahan pelaksanan supervisi.

Implementasi di lapangan banyak ditemukan masalah-masalah yang masih menghambat terlaksananya supervisi, di antaranya (Tim Dosen Administrasi Pendidikan UPI, 2010) 1) sistem kerja sentralisasi yang masih melekat. Guru perlu pembiasaan budaya kerja baru sesuai semangat otonomi pendidikan dan otonomi daerah yang menuntut kreatifitas dan kerja 
keras. Kebiasaan lama dalam bekerja harus sudah ditinggalkan; 2) persaingan mutu sekolah semakin terasa berat. Pembinaan pembelajaran harus dilakukan dengan serius dan sungguh-sungguh; 3) masih adanya mental anak emas untuk guru yang dinilai dan baik; 4) tuntutan akuntabilitas penyelenggaraan sekolah dari masyarakat yang semakin tinggi, menyebabkan kesibukan dalam menangani urusan administrasi, terutama menghadapi pemeriksaan pembukuan, LSM dan Pers; 5) transparansi manajemen sekolah yang sering terjadi benturan kebijakan dengan komite sekolah, menyebabkan kesulitan bergerak untuk kelancaran tugas-tugas rutin; dan 6) transparansi pengelolaan keuangan sekolah yang pembukuan dan bukti-buktinya menyita banyak waktu.

Usaha untuk kelancaran dan keberhasilan pemecahan permasalahan yang ditempuh dalam kegiatan supervisi oleh kepala sekolah adalah sebagai berikut (Tim Dosen Administrasi Pendidikan UPI, 2010) 1) penyamaan visi dan misi; 2) pengelolaan supervisi yang baik; 3) pelibatan guru secara individual dalam pelaksanaan supervisi; dan 4) pelibatan organisasi guru, seperti PKG, KKG, dan KKKS untuk mengukur keberhasilan guru dalam pembelajaran dan sebagai tempat bertukar pendapat dan menggali ide-ide kreatif.

\section{METODE PENELITIAN}

Penelitian ini bermaksud untuk melihat bagaimana implementasi supervisi akademik Kepala MIS Batusangkar. Dalam penelitian ini peneliti menggunakan pendekatan kualitatif, yang mana dalam pendekatan kualitatif tersebut adalah menjabarkan dari setiap fenomena-fenomena yang tampak dari lapangan dan kemudian mencocokannya dengan teori yang ada. Menurut Moleong (1991) data dalam penelitian kualitatif diperoleh melalui literatur dan melalui lisan serta hasil observasi, wawancara dan dokumentasi kemudian dianalisis dan dikompromikan secara kritis. Metode wawancara yang digunakan di dalam penelitian ini adalah menanyakan dan mewawancarai proses supervisi yang dilakukan oleh Kepala MIS Batusangkar.

Metode wawancara yang digunakan dalam melakukan penelitian ini adalah bagaimana implementasi supervisi ajademik Kepala MIS Batusangkar. Wawancara pertama kali kami lakukan adalah dengan Kepala MIS Batusangkar. Dalam wawancara yang dilakukan peneliti mengumpulkan informasi dari Kepala Sekolah tentang bagaimana implementasi yang dilakukan oleh Kepala MIS Batusangakar. Kemudian wawancara selanjutnya peneliti lakukan kepada guru-guru MIS Batusangkar, guruguru yang kami wawancarai sebanyak 3 orang 
yaitu Dasmati, S.Pd.I, Fitri Dona, S.Pd.I, Khairul Muslim, S.Pd.I, peneliti menanyakan bagaimana implementasi yang dilakukan oleh Kepala Sekolah terhadap guru-guru di MIS Batusangkar.

Menurut Sudjana (2000) wawancara adalah proses pengumpulan data atau informasi melalui tatap muka antara pihak penanya (interviewer) dengan pihak yang ditanya atau penjawab. Metode wawancara yang digunakan dalam penelitian ini adalah wawancara tidak terstruktur. Data yang diperoleh melalui metode wawancara ini juga untuk melengkapi data yang diperoleh melalui metode observasi, sehingga data yang diperoleh lebih lengkap dan mendalam. Dengan demikian, metode wawancara ini merupakan triangulasi pengumpulan data atas data observasi. Menurut Moleong (2005) triangulasi adalah teknik pemeriksaan keabsahan data yang memanfaatkan sesuatu yang lain. Teknik triangulasi yang paling banyak digunakan ialah pemeriksaan melalui sumber lainnya.

\section{HASIL PENELITIAN DAN} PEMBAHASAN

\section{Implementasi Supervisi}

Dari hasil wawancara dengan Kepala MIS Batusangkar bahwa pelaksanaan yang dilakukan pertama kali oleh Kepala MIS Batusangkar adalah membuat perencanaan terlebih dahulu, kemudian melaksanakannya, dan mengnindaklanjuti dari pelaksanaan supervisi tersebut. Hal tersebut dilakukan kerena menurut Kepala MIS Batusangkar adalah agar semua kegiatan supervisi dapat terprogram dengan baik dan mampu mencapai tujuan dari diadakannya kegiatan supervisi tersebut. Hal yang dilakukan oleh Kepala MIS Batusangkar tersebut mempuyai kesamaan dengan yang dibuat oleh Tim Pakar Manajemen Pendidikan. Tim Pakar Manajemen pendidikan menyebutkan bahwa dalam pelaksanaan supervisi dilaksanakan dalam tiga tahap yakni perencanaan, pelaksanaan, dan evaluasi. Begitu juga menurut Asmendri (2012: 145-146) bahwa pelaksanaan supervisi terdiri dari tiga tahapan yaitu perencanaan, pelaksanaan, dan evaluasi.

a. Perencanaan

Setiap kegiatan haruslah dimulai dengan perencanaan, tidak terkecuali supervisi oleh kepala sekolah. Menurut Kepala MIS Batusangkar hal pertama sebelum melaksanakan supervisi adalah membuat perencanaan. Beliau juga mengungkapkan bahwa tujuan dari pembuatan perencanaan dalam supervisi adalah supaya program dari supervisi tersebut dapat terprogram dengan baik dan dapat mencapai dari tujuan supervisi tersebut. 
Dalam perencanaan supervisi ada beberapa hal yang harus terdapat di dalamnya antara lain penentuan tujuan, waktu pelaksanaan, dan pembuat jadwal supervisi. Dalam wawancara, beliau mengatakan bahwa dalam hal yang terdapat dalam perencanaan adalah menetukan tujuan dan membuat jadwal. Hal tersebut diperkuat dengan wawancara bersama guru-guru di MIS Batusangkar yaitu Dasmati, S.Pd.I, Fitri Dona, S.Pd.I, Khairul Muslim, S.Pd.I yang mengatakan bahwa sebelum melaksanakan supervisi membuat jadwal terlebih dahulu yang kemudian ditempel di mading sekolah, hal tersebut dilakukan agar guru-guru dapat melihat jadwal tersebut dan siap pula disupervisi dengan waktu yang telah ditetukan karena telah mengetahui kapan akan di supervisi.

Dari temuan peneliti tentang perencanaan supervisi Kepala MIS Batusangkar mempunyai kesamaan pendapat dengan Asmendri (2012: 145) bahwa hal yang harus dicantumkan dalam perencanaan supervisi adalah tujuan supervisi, alasan mengapa kegiatan tersebut dilaksanakan, bagaimana metode/teknik mencapai tujuan yang telah dirumuskan, siapa yang akan dilibatkan, waktu pelaksanaan, dan hal-hal yang diperlukan dalam pelaksanaannya serta bagaimana memperoleh hal-hal tersebut.

b. Pelaksanaan

Pelaksanaan supervisi berkaitan dengan bagaimana seorang supervisor menjalankan apa yang telah direncanakan sebelumnya. Dalam wawancara dengan Kepala MIS Batusangkar, peneliti menemukan bahwa pelaksanaan dilakukan dengan cara langsung berada di dalam kelas saat guru-guru mengajar, melihat dan memperhatikan bagaimana cara guru mengajar dan kesesuaian materi ajar dengan peserta didik yang ada di MIS Batusangkar. Setelah melakukan pengamatan dan penilaian terhadap guru, Kepala MIS Batusangkar juga memanggil guru ke ruangan Kepala Sekolah untuk langsung mengatakan kekurangankekurangan guru yang bersangkutan dan memberikan solusi dari permasalahan yang ada contohnya dalam menggunakan metode megajar guru, ketika melakukan pengamatan langsung metode yang digunakan salah maka akan saya perbaiki setelah guru tersebut selesai mengajar. Hal tersebut dilakukan supaya tidak menganggu jalannya proses pembelajaran.

Kemudian setelah melakukan wawancara kepada Kepala Sekolah, peneliti juga melakukan wawanca dengan guru-guru yaitu Dasmati, S.Pd.I, Fitri 
Dona, S.Pd.I, Khairul Muslim, S.Pd.I.

Pertama kami lakukan wawancara dengan ibu Dasmati, S.Pd.I, yang mengemukakan bahwa pelaksanaan supervisi yang dilaksanakan oleh Kepala MIS Batusangkar adalah dengan cara mengamati guru yang sedang mengajar, dan melakukan penilaian terhadap guru yang sedang mengajar. Hal serupa juga disampaikan oleh Fitri Dona, S.Pd.I, dan Khairul Muslim, S.Pd.I, mereka menyampaikan bahwa pelaksanaan yang dikukan oleh Kepala MIS Batusangkar adalah melakukan pengamatan langsung guru mengajar dan melakukan penilaian terhadap kinerja guru. Kemudian guruguru yang kami wawancarai tersebut juga menyatakan pernyataan yang sama bahwa setelah melakukan pengamatan dan penilaian kami dipanggil oleh Kepala Sekolah ke ruangannya untuk diberikan masukan terhadap kekurangan dan kesalahan yang beliau lihat. Kemudian Kepala Sekolah tidak hanya memberikan masukan terhadap kekurangan dan kesalahan, beliau juga memberikan masukan terhadap kekurangan dan kesalahan dari kinerja para guru. Dari hasil wawancara tersebut terdapat kesamaan dengan pendapat Asmendri (2012: 145), yang mengungkapkan bahwa pelaksanaan supervisi meliputi beberapa kegiatan yaitu pengumpulan data, penilaian, deteksi kelemahan, memperbaiki kelemahan, bimbingan dan pengembangan.

c. Evaluasi

Evaluasi merupakan tahap penilaian setiap kegiatan yang dilaksanakan, apakah sudah sesuai dengan tujuan yang ditetapkan atau belum. Menurut Asmendri (2012: 22) evaluasi merupakan akktivitas untuk meneliti dan mengetahui sampai mana pelaksanaan yang dilakukan di dalam proses keseluruhan organisasi mencapai hasil sesuai dengan rencana atau program yang telah ditetapkan dalam rangka pencapaian tujuan pendidikan. Kemudian Fayol (Daryanto, 2013: 48) juga mengemukakan bahwa evaluasi adalah proses menilai semua kegiatan untuk menemukan indikator yang menyebabkan sukses atau gagalnya pencapaian tujuan, sehingga dapat dijadikan bahan kajian berikutnya. Dalam supervisi, evaluasi lebih dikenal dengan tindak lanjut. Dalam wawancara dengan Kepala MIS Batusangkar bahwa tindak lanjut yang dilaksanakan adalah apabila dalam pelaksanaan supervisi setalah diberikan masukan tapi kekurangan tersebut masih tidak bisa di atasi maka guru yang bersangkutan akan diikutsetakan dalam kegiatan ilmiah, seperti workshop, pelatihan, seminar, $\mathrm{KKG}$, hal tersebut 
dilakukan untuk meningkatkan pengetahuan dan ketrampilan guru.

Kemudian dalam wawancara dengan guru-guru Dasmati, S.Pd.I, Fitri Dona, S.Pd.I, dan Khairul Muslim, S.Pd.I mengatakan hal yang sama. Menurut para guru tersebut evaluasi yang dilaksanakan merupakan tindak lanjut dari pelaksanaan supervisi yang dilaksanakan, hal tersebut dilakukan guna meningkatkan kemampuan dan keterampilan guru. Kegiatan yang dilakukan adalah dengan menyuruh guruguru untuk mengikuti kegiatan ilmiah, seperti workshop, pelatihan, seminar, KKG.

\section{Metode dan Teknik Supervisi}

Dalam wawancara dengan Kepala MIS Batusangkar, mengatakan bahwa metode yang digunakan saat melakukan supervisi adalah sebagai berikut:

a. Rapat dewan guru

Dari hasil wawancara dengan kepala sekolah MIS Batusangkar, metode atau teknik rapat dewan guru yang dilakukan dalam supervisi. Metode tersebut dianggap efektif untuk menyelesaikan masalah yang tidak bisa diselesaikan sendiri oleh Kepala Sekolah. Melalui rapat dewan guru inilah semua permasalahan dapat di atasi secara bersama-sama. Saya juga menerapkan rapat dewan guru sebagai salah satu metode supervisi. Hal ini dilakukan untuk memberikan informasi kepada guru-guru. Selain itu, rapat ini juga untuk mengevaluasi program dan untuk momotivasi guru-guru dalam melaksanakan tugasnya dalam mengajar. Kemudian beliau juga mengatakan, diterapkannnya rapat dewan guru sebagai metode supervisi adalah untuk meyatukan pendapat tentang suatu permasalahan yang terjadi, untuk memotivasi guru untuk lebih giat bekerja dan menghimpun pendapatpendapat tentang metode kerja yang efektif dan efisien.

b. Kunjungan kelas

Kunjungan kelas meupakan kegiatan yang dilakukan oleh seorang supervisor untuk melihat bagimana kinerja guru di dalam kelas. Dari hasil wawancara yang dilakukan bersama Kepala MIS Batusangkar, bahwa dalam pelaksanaan kujungan kelas tersebut adalah dengan cara mengamati secara langsung di dalam kelas tersebut tentang bagaimana guru mengajar di dalam kelas. Yang menjadi fokus utama saat melakukan kunjungan kelas adalah apakah metode yang digunakan guru saat pembelajaran dengan materi yang diajrakan, jangan sampai nantinya pada materi yang mengharuskan memakai metode praktek yang digunakan malah metode ceramah. Hal tersebut merupakan 
salah satu manfaat dari dilakukan kunjungan kelas, manfaat yang lain adalah dapat secara langsung melihat kekurangan dan permasalahan guru mengajar, dengan langsung mengamati maka akan lebih mudah mencari solusinya.

Kemudian dari hasil wawancara dengan Dasmati, S.Pd.I, Fitri Dona, S.Pd.I, dan Khairul Muslim, S.Pd.I. mengatakan hal yang sama. Guru-guru tersebut mengatakan bahwa dalam pelaksanaan kunjungan kelas, kepala sekolah langsung mengamati bagaimana kinerja guru, metode yang dipakai oleh guru, dan permasalahan pada saat mengajar.

\section{c. Pembicaraan individual (pribadi)}

Pembicaraan individual merupakan salah satu teknik supervisi yang dilakukan berdua saja antara Kepala Sekolah dan guru. Menurut Sehertain (2000: 73) pembicaraan pribadi merupakan percakapan yang dilakukan oleh Kepala Sekolah dalam rangka menyelesaikan problem yang dihadapi oleh guru. Dari hasil wawancara dengan Kepala Sekolah, pelaksanaan pembicaraan pribadi biasanya dilakukan dengan pertemuan secara formal, ini terjadi karena saya selaku Kepala Sekolah menganggap perlu untuk memanggil guru yang bisanya saya lakukan di rungan Kepala Sekolah, karena beberapa alasan seperti absensi kehadiran guru yang masih sangat kurang, terjadinya kegaduhan di kelas, rendahnya hasil pembelajaran siswa, dan karena hasil supervisi kunjungan dan observasi kelas yang menemukan rendahnya kompetensi pedagogik guru dalam melaksanakan proses pembelajaran.

Dari hasil wawancara dengan guruguru Dasmati, S.Pd.I, Fitri Dona, S.Pd.I, dan Khairul Muslim, S.Pd.I, juga mengungkapkan hal yang sama dan mendukung dari apa yang telah dikatakan oleh Kepala Sekolah pada saat diwawancarai. Guru-guru tersebut mengatakan bahwa setelah Kepala Sekolah melakukan pengamatan di dalam kelas kemudian setelah pembelajaran selesai dilaksanakan, Kepala Sekolah kemudian memanggil guru yang telah diawasi ke dalam ruangan Kepala Sekolah yang bertujuan untuk memperbaiki kinerja guru dalam mengajar.

Jadi, dari paparan yang berkaitan dengan teknik atau metode, Kepala MIS Batusangkar menggunakan 3 teknik yaitu rapat dewan guru, kunjungan kelas dan pembicaraan individu atau pribadi. Ketiga teknik tersebut sangat efektif dilakukan di MIS Batusangkar.

3. Respon Guru terhadap Pelaksanaan Supervisi Akademik Kepala Sekolah 
Respon guru terhadap pelaksanaan supervisi akademik kepala sekolah adalah bagaimana tanggapan yang diberikan oleh guru terhadap pelaksanaan supervisi oleh kepala sekolah. Dari hasil wawancara yang dilakukan kepada Kepala MIS Batusangkar, beliau menjawab kalau guru sangat merespon positif mengenai supervisi yang dilaksanakan oleh kepala sekolah.

Kemudian hasil wawancara dengan guru Dasmati, S.Pd.I, beliau mengatakan bahwa supervisi yang dilakukan oleh Kepala Sekolah itu bagus, hal tersebut dikarenakan itu sudah menjadi tugas dari Kepala Sekolah dalam melakukan pengawasan terhadap guruguru. Kemudian dari hasil wawancara dengan Khairul Muslim, S.Pd.I, beliau mengatakan sebagai supervisor, dalam bidang ini Kepala Sekolah telah menyelenggarakan supervisi terhadap proses belajar mengajar, kegiatan bimbingan dan konseling, kegiatan ekstrakurikuler, kegiatan ketatausahaan, kegiatan kerja sama dengan masyarakat dan instansi yang terkait, kegiatan OSIS dan lainlain. Kegiatan ini dilakukan dalam jenjang tertentu seperti supervisi bulanan, semester, dan tahunan. Kemudian yang terakhir dengan Fitri Dona, S.Pd.I, beliau mengatakan bahwa pelaksanaan supervisi oleh kepala sekolah sangat bagus digunakan, karena dapat mengubah kinerja guru menjadi lebih baik.

\section{KESIMPULAN}

Dalam implementasi supervisi akademik, Kepala MIS Batusangkar membuat perencanaan terlebih dahulu, kemudian melaksanakannya, dan mengnindaklanjuti dari pelaksanaan supervisi tersebut. Teknik yang digunakan dalam supervisi akademik adalah 1) rapat dewan guru; 2) kunjungan kelas; dan 3) pembicaraan individu atau pribadi. Guru sangat merespon positif mengenai supervise akademik yang dilaksanakan oleh Kepala MIS Batusangkar.

\section{DAFTAR PUSTAKA}

Asmendri. (2012). Teori dan Aplikasi Manajemen Peningkatan Mutu Pendidikan Sekolah dan Madrasah. Batusangkar: STAIN Batusangkar Press.

Daryanto, M. (2014). Administrasi dan Manajemen Sekolah. Jakarta: PT Rineka Cipta.

Emzir. (2013). Metodologi Penelitian Kualitatif. Jakarta: PT Raja Grafindo Persada.

Engkoswara dan Komariah. (2010). Administrasi Pendidikan. Bandung: Alfabeta.

Iskadar, M. d. (2009). Orientasi Baru Supervisi Pendidikan. Jakarta: Gaung Persada.

Jasmani dan Mustafa, Syaiful. (2013). Supervisi Pendidikan. Jokyakarta: ArRuzz Media. 
Maryono. (2011). Dasar-Dasar dan Teknik Menjadi Supervisor Pendidikan. Yokyakarta: AR-Ruzz Media.

Moleong, L. J. (2005). Metodologi Penelitian Kualitatif. Bandung: Remaja Rosdakarya.

Mulyasa, E. (2013). Manajemen Kepemimpinan Kepala Sekolah. Jakarta: Bumi Aksara.

- (2007). Menjadi Kepala Sekolah Profasional. Bandung: Remaja Rosdakarya.

- (2004). Menjadi Kepala Sekolah Profesional. Bandung: Remaja Rosdakarya.
Mustofa, J. D. (2013). Supervisi Pendidikan; Terobosan Baru dalam Peningkatan Kinerja Pengawas Sekolah dan Guru. Yokyakarta: AR-Ruzz Media.

Sahertian, P. A. (2000). Konsep Dasar dan Teknik Supervisi Pendidikan dalam Rangka Pengembangan Sumber Daya Manusia. Jakarta: Rineka Cipta.

Somad, D. J. (2014). Manajemen Supervisi dan Kepemimpinan Kepala Sekolah. Bandung: Alfabeta.

Undang-Undang No. 20 Tahun 2003. Sistem

Pendidikan Nasional. 